\title{
Dekonstruksie van tradisionele probleem- realiteite: 'n Narratief-pastorale perspektief
}

\author{
J J de Jager \& J C Müller ${ }^{1}$ \\ Departement Praktiese Teologie \\ Universiteit van Pretoria
}

\begin{abstract}
Deconstruction of traditional problem realities: A narrativepastoral perspective.

This article serves as an introduction to qualitative narrative research from a postmodern epistemological perspective. The research is directed at four pastoraltherapeutic processes and the stories told as part of those processes. Special focus is placed on the construction and deconstruction of problems in the fields of action: authority; typification; institutionalization. Perspectives regarding narrative, social constructionism, deconstruction and post-modern theology, are explained. The article positions itself in the practical research-processes:
\end{abstract}

\section{DOEL EN RELEVANSIE VAN DIE NAVORSING}

\subsection{Praktiese wysheid}

Die doel van die navorsing was om tot praktiese wysheid te kom (Browning 1991:1,2). Die praktykhandelinge wat nagevors en beskryf is, was die aksies van die navorsers ${ }^{2}$ in vier pastoraal-terapeutiese prosesse, sowel as die handelinge van andere wat optree in die verhale wat vertel is.

\footnotetext{
${ }^{1}$ Hierdie artikel dien as bekendstelling van kwalitatiewe narratiewe navorsing wat gedoen en beskryf is in 'n gedeelte van die proefskrif wat gedien het as vervulling van die vereistes vir ' $\mathrm{PhD}$-graad, Praktiese Teologie, Universiteit van Pretoria, onder promotorskap van prof dr J C Müller.

2 Die persone wat saam met my betrokke was in die terapeutiese prosesse, word beskou as ko-navorsers (Müller, van Deventer \& Human 2001:77).
} 
In aansluiting by Müller (1996:1, 2) geld die konsep toepassing nie vir hierdie navorsing nie, aangesien hierdie konsep sou kon impliseer dat die beweging in die prosesse net of hoofsaaklik van teorie na praktyk was. Die meer teoretiese uitgangspunte van die navorsingsverslag dien eerder as parameters/riglyne en verduideliking van my posisionering as pastor-navorser binne die pastoraal-terapeutiese prosesse waarbinne ek betrokke geraak het.

Hierdie standpunt oor toepassing moet verder ook verstaan word in die lig daarvan dat die navorsing narratiewe navorsing was. Verhale is as navorsingsmateriaal beskou (vgl Lieblich, Tuval-Mashiach \& Zilber 1998:2; Mishler 1986:68), maar die prosesse self is ook as navorsingsverhale en daarom as navorsingsmateriaal beskou (vgl Müller et al 2001:1-13).

Mense is toegelaat om verhale te vertel, sonder beperking van gespesifiseerde vrae waarop "relevante" antwoorde verkry moes word. Binne hierdie ongestruktureerde prosesse het ek daarteen gewaak om nie die gesprekke oor te neem en die eie stemme van die andere stil te maak nie (vgl Mishler 1986:69). Wyer prentjies het sodoende na vore gekom. So 'n benadering kan nie meer geredelik in terme van toepassing verstaan word nie. Dit mag wel chaoties klink vir diegene wat navorsing doen onder streng metodologiese voorwaardes van spesifikasie, beheer en stuur. Dit bring egter vloei, terwyl engheid en beperktheid teengewerk word. 'n Groot bedreiging vir wetenskapsbeoefening is juis wat Polkinghorne (1994:5) noem "a narrow reductionist conception of reality."

Hierdie manier van werk pas ook gemaklik in by 'n postmoderne epistemologie. Kennis realiseer nie binne subjek-objekverhoudings waarin die navorser 'n buiteposisie het met die oog op objektiewe kennis nie. Marshall (1992:188) vra vir die voortdurende bewustheid van "being-within", en die handhawing van hierdie posisie. Kenne moet as plaaslik en in terme van pluraliteit, kontekstualiteit en temporaliteit bedink word (Brueggemann 1993:8-9). Veelheid, verskillendheid, kompleksiteit en verskuiwing/ beweging problematiseer die modernistiese ideaal, naamlik: insig in objektiewe, universele, tydlose, absolute waarheid onder leiding van die rede en na aanleiding van vermeende begrondinge (Nealon 1993:88) en logosentrismes (Marshall 1992:20).

Kennis realiseer binne taalspel. Woorde verwys slegs na ander woorde, binne "an interplay of signifying elements" (Elam 1992:140). In die lig hiervan is 'n gespreks- 
benadering met die oog op praktiese wysheid van besondere belang. Tydens die navorsing is moeite gedoen om die proseshandelinge te laat realiseer binne terapeutiese diskoers wat as gesprek beskryf kan word.

Ek het gekies vir 'n navorsingsmetodologie waarin metodes, modelle, agendas en prosedures in diens moes staan van narratiewe navorsing, in samehang met 'n postmoderne benadering/oriëntering en meer spesifiek: postmoderne epistemologie. Daar is slegs van gespreksagendas gebruik gemaak met die oog op eind-reflekterings deur die ko-navorsers. Hierdie agendas was binne gesprekke gebruik, om sodoende 'n "ondervrastyl" te deurbreek. Ek het veral aansluiting gevind by Re-authoring therapy (kyk White \& Epston 1990; Freedman \& Combs 1996). Dit is gedoen met inagneming van Gergen (1994:250) se kritiek, naamlik dat Re-authoring therapy die saad van voorskriftelike rigiditeit dra en daarom vir hom lyk na 'n eerste-orde (modernisties kubernetiese) terapeutiese benadering. Enige terapeutiese model dra egter die kiem van rigiditeit en dwangmatige "toepassing", en daarteen is gewaak in die navorsing.

\subsection{Spesifieke aksievelde en probleemrealiteite}

Hierdie navorsing se relevansie hang veral saam met die spesifieke aksievelde (Müller et al 2001:81) en gepaardgaande probleemrealiteite waarop gefokus is, en die kontekste van die plattelandse gemeenskap waarbinne die navorsers leef.

In die vier prosesse wat beskryf word, is dikwels beweeg op die aksievelde outoriteit, tipering en tradisionele instellings. Geen gesprek/proses is gestuur in die rigting van die vermelde aksievelde nie. In narratiewe navorsing is die fokus eerstens op mense en nie op aksievelde nie (Müller et al 2001:86). Die prosesse wat beskryf is, was gekies uit baie prosesse waarin ek betrokke was in die gang van my pastoraal-terapeutiese bediening. Nie net gemeentelede word pastoraal bedien nie.

Die plattelandse gemeenskap is familie-intensief, kerk-intensief en sterk geïntegreerd in terme van woonwêreld en werkswêreld. Patriargale waardes funksioneer nog sterk in die gemeenskap. Die NG Kerk is ' $n$ invloedryke tradisionele instelling. Daar is egter ook onrustigheid, onsekerheid en spanning vanweë verskuiwings in waarde- en geloofsoriënterings. Geen tiperende kategorisering kan egter reg laat geskied aan die lewe van 'n gemeenskap nie, en ek het dit in gedagte gehou in die navorsingsproses. 
Probleemrealiteite wat verband hou met outoritarisme, stereotipering en tradisionalisme, is gekonstrueer en gedekonstrueer binne die prosesse.

\subsection{Reflektering op die navorsingsprosesse}

Praktiese teologie is die sistematies-gestruktureerde, voortgaande hermeneutiese proses, waardeur gepoog word om teologies verhelderend en vernuwend te reflekteer op menslike handelinge wat verband hou met die verhale van die Christengeloofsgemeenskap (Müller 1996:5). Sodanige reflektering het plaasgevind en is beskryf. Sommige reflekterings het plaasgevind as deel van die prosesse, ander reflekterings is deur my gemaak tydens die beskrywing van die prosesse. Die ko-navorsers het die "laaste" woord ingekry: hulle het gereflekteer op die prosesse sowel as op van my reflekterings op die prosesse. Die navorsing word nou bekendgestel vir verdere reflektering - onder meer prakties-teologies - deur die lesers.

\section{$1.4 \quad$ Etiese verantwoording}

Dit is 'n groot uitdaging en verantwoordelikheid vir 'n narratiewe navorser om eties verantwoord sowel as wetenskaplik relevant te wees. Deur die uitgebreide beskrywing van mense se stories word hulle lewens meer blootgelê as in ander kwalitatiewe navorsing. Hulle word meer kwesbaar gelaat (kyk Chase 1996:46), en benodig beskerming wanneer die stories en prosesse openbaar gemaak word (kyk Bakan 1996:5). Elke leser van my navorsingsverslag dra 'n groot etiese verantwoordelikheid met betrekking tot vertroulikheid. Daar is nie 'n kopie van die navorsingsverslag op my boekrak in die gemeente nie en dit is ook nie vryelik beskikbaar nie.

Hoewel my ko-navorsers toestemming gegee het dat die prosesse as navorsingsmateriaal gebruik kan word, is daar aspekte van die navorsingsprosesse waaroor ek nie verslag kon doen nie, in die lig van ingrypende implikasies vir die ko-navorsers en andere. Soms is gegewens verander ten einde gespreksgenote te beskerm. Ek handel in die verslag oor die dilemmas van dekontekstualisering van navorsingsgebeure.

\section{VERDERE VERDUIDELIKING VAN POSISIONERING}

Ek verduidelik vervolgens kortliks - in neutedoppe - perspektiewe met betrekking tot narratief, dekonstruksie, sosiale konstruksie en postmoderne teologie, in die lig waarvan 
ek my geposisioneer het binne die praktiese navorsingsprosesse. Hierdie neutedoppe het nie die pretensie van waarheid nie. Neutedoppe reduseer en vereenvoudig. Dekonstruksie kompliseer, vermeerder, breek neutedoppe oop en belig meer moontlikhede (Caputo 1997:31).

\subsection{Narratief}

Epston, White en Murray (1992:97) beskryf die storievorm as die dominante interpretasieraamwerk vir die organisering en uitbeelding (patterning) van beleefde ervaring. Deur na verhale as raamwerke te verwys, word aandag daarvoor gevra dat verhale, as interpretasie van ervaring, opgemaak word uit slegs maar 'n gedeelte van ervaring.

Die storieraamwerk word oor 'n (tyds)vloei van ervaring geplaas. In elke storie word arbitrêre keuses gemaak vir begin en einde. Sommige gebeure, persone, kontekste en refleksies word uitgelig, andere word uitgelaat. 'n Storie is altyd 'n bepaalde interpretasie van dit wat verhaal word, en nooit ' $n$ ware beskrywing daarvan nie. Al ons ervarings kan gestorie word, en al die stories van ons lewe saam vorm ons lewensverhaal. Dit is die vertel van onsself. "Met verhale konstrueer ons ons lewe. Die verhale in ons geheue, of dit nou oorvertel word of nie, is die raamwerk wat ons help om sin te maak uit die lewe" (Müller 2000:9). Hierdie stories vorm ons identiteit (Müller 2000:71). 'n "Permanente" self is ' $n$ illusie. Ons self kom na vore in die voortgaande verhale van ons interaksie met andere (Lax 1992:71).

\subsection{Dekonstruksie}

\subsubsection{Dekonstruksie van Westerse filosofie}

Die Westerse filosofie se logosentrisme behels dat alle tekens/betekening gekonstitueer/ begrond is deur en in 'n bepaalde logos - dit wat beskryf kan word in terme soos: oorspronklik; essensieel; wet van God; Being; woord van God; God self; ensovoorts (Derrida 1976:14). Die bestaan van die logos-struktuur hang saam met bepaalde hiërargiese onderskeidings in die spel van betekening, byvoorbeeld: "The voice is closest to the signified .... The written signifiers are always technical and representative" (Derrida 1976:11). Sodoende word die geskrewe woord gedegradeer tot tweedehandse 
taal, tot teken van 'n teken (Derrida 1976:7). Derrida het die "redelike" en daarom "waarheid" van hierdie aannames begin ondermyn deur 'n dekonstruktiewe beweging, en sodoende die bestaan van die logos-struktuur self onder verdenking gebring. 'n Metafisiese struktuur is gedekonstrueer wanneer die een nie langer - logosentries - duidelik blyk voorrang te moet geniet bo die ander nie (Derrida 1976:28).

In sy dekonstruktiewe lees van De Saussure byvoorbeeld, blyk 'n belangrike aspek van Derrida se dekonstruktiewe beweging te wees: bring die ondergeskikte/gemarginaliseerde in spel, nie van buite nie, maar na aanleiding van innerlike spanninge in die aanvanklike spel van uitsluiting/marginalisering. Die hiërargie sou selfs moontlik omgekeer kan word (Derrida 1976:30-36).

'n Dekonstruktiewe beweging beoog egter nie 'n nuwe/omgekeerde hiërargie nie, maar eerder 'n bewusmaking van die onmoontlikheid om te kies vanweë die gekompliseerdheid van die spel. Die nuwe hiërargie word ook onder verdenking geplaas. Dekonstruksie is nie 'n kritiese beweging wat die waarheid en vaste begronding van argumente probeer vervang of aanvul met ander, beter argumente nie (Gasché 1987:4; Moyaert 1986:33). Derrida (1988:3-4) beskou nie dekonstruksie as 'n metode nie en dit kan ook nie verander word tot 'n metode nie. Wat hy beoog het, kan op enige manier gedoen word, vanuit verskillende perspektiewe en beweegredes (Derrida 1996:85). Dekonstruksie vra eerder vir 'n "self-revising, self-questioning mode of openness" (Caputo:1997:73).

'n Speelse skepping van Derrida, naamlik différance, kom in Marges de la philosophie (1972) na vore. Daardeur speel hy dekonstruktief met die Westerse metafisika se pretensies van vaste en sekere betekenis oor wat kern, sentrum, oorspronklik en essensieel is. Play of difference in die gebruik van taal word ook deur hierdie skepping belig. Derrida se semantiese uitmekaarhaal van différance bring hom by die onderskeidings différer, differ en defer (Derrida 1982:8,18). Betekeniskonstruering behoort uitgestel, vertraag, herlei, aangevul en teruggehou te word. Dekonstruksie is egter nie krities of nihilisties nie (Ijsseling 1986:13), maar vermeerder/open betekenismoontlikhede. As dekonstruksie moet kies vir 'n bepaalde moontlikheid, sou die keuse wees: ja en nee (Nealon 1993:161). 
Die verskillende teken-elemente in die weefspel van betekening is onoorsigtelik baie. Die ander - dikwels teenoorgestelde, gemarginaliseerde of gedegradeerde moontlike tekens/metafore is as spore (traces) beskikbaar om na vore geroep te word en ingetrek te word in die taalspel. "... [T] hese new distinctions are not like artifacts, waiting to be discovered, but different views available to each reader based on that person's perspective within which she views the text" (Lax 1992:72).

Die taalspel is 'n dinamiese spel van byvoeging en vervanging, supplementarity, sonder 'n sentrum wat die spel absoluut begrond (Marshall 1992:68). Dekonstruksie is reaktief. Dit werk in die marge van bestaande tekste. "Deconstruction lies in wait for discourse to stake its claims and then it pounces on it, showing how much trouble this discourse has brought for itself by its boldness" (Caputo 1989:31). Dekonstruksie vra, eties gesproke, ruimte vir die andersheid van die ander. "Deconstruction will favor the discourses of the marginalized" (Farrell 1994:261). Dekonstruksie maak oop en maak los ter wille van lewensmoontlikhede, sodat daar nie in rigiditeit en marginalisering begrond in die "waarheid" van 'n vermeende logos-struktuur - versand word nie.

\subsubsection{Dekonstruksie van verhale}

"All meaning, understanding, and interpretation are inherently negotiable and tentative" (Anderson \& Goolishian 1988:381). Verhale is hoogs onstabiele supplements, interpretasies van gebeure en refleksies op gebeure, vanuit bepaalde perspektiewe. Dekonstruksie van narratiewe is om in die "ware" verhale wat vertel word die spoor te vat van (teenoorgestelde) moontlikhede wat nie verreken word nie, en dit in te trek in die gesprek. Wanneer die waarheidspretensie van die storie ontmasker word, verloor die storie en die verteller hulle mag en kan gemarginaliseerde moontlikhede ook sanksie verkry. Terapie kan dus beskou word as 'n dekonstruktiewe taalbeweging en storiebeweging, in différance. "With this interplay of the said and the non-said, the present and the not-present, there is always the potential for another position or perspective, which has not yet been distinguised, to emerge" (Lax 1992:72). Die narratiewe terapeut stel eerder keuses uit en vermeerder moontlikhede. 


\subsection{Sosiaal-konstruksionisme}

Sosiale konstruksionisme behels die beklemtoning van die sosiale prosesse waarvolgens kennis - menings (beliefs), waardes, tiperings, instellings, wette, rolverdelings ensomeer - ontwikkel binne kulture, van dag tot dag en van geslag tot geslag (Freedman \& Combs 1996:16; Müller 2000:58). Ook dit wat as probleme beskou word en hoe in die lig daarvan gehandel word, hang saam met hierdie soort "social regularities" (Scheurich 1998:97-102). Probleme is ook sosiale konstruksies wat eers ontstaan wanneer iemand dit konstrueer binne 'n bepaalde kultuur vanuit 'n bepaalde perspektief.

\subsubsection{Prosesse van reification}

Sosiale konstruksies kry maklik, met verloop van tyd, die stempel van waarheid objektiewe realiteit wat vas staan - en word sodoende verhef tot bo- of buitemenslike gegewens. Sodanige reification word prosesmatig voltrek (Freedman \& Combs 1996:2328, in aansluiting by Berger \& Luckman 1966). In die proses word onder meer tiperings en instellings van 'n bepaalde samelewing gelegitimeer.

Ons sosiale werklikhede word gekonstitueer rondom netwerke van tiperings. Verskille word gesorteer en in terme van tipes en sub-tipes geklassifiseer, byvoorbeeld: afkoms; verwantskap; geslag; ras; persoonlikheid; lewensfase; status; geloof; waardes; gesondheid. Binne geloof sou byvoorbeeld nog verder tipeer kon word: Moslem; Christen; gereformeerd-Christelik; charismaties-Christelik.

Stereotipering kan beskou word as die rigiede vaslegging van tiperings (De Villiers et al 1985). Stereotipering behels ook verskraling en veralgemening (Owen 1993:16, 17). Mense word verskralend beskryf in terme van enkele tiperende kenmerke van hulle bestaan. Deur veralgemening word verskille geïgnoreer en eendersheid gepropageer. Vanuit 'n dualistiese perspektief word verskillende aspekte as onafhanklik en onderling uitsluitend hanteer (Lamprecht 1996:49).

Instellings kom tot stand rondom tiperings. Dit kan skriftelik vasgestel word in wette, gedragskodes, organigramme, reëls, openbaringsboeke, belydenisskrifte of ordes. Instellings kan ook as ongeskrewe sosiale konstruksies tot stand kom, byvoorbeeld moederskap (Derrida 1997:27) en patriargie. In die patriargie word aan die man en vaderfiguur oppergesag toegeken (Marshall 1992:59; Lamprecht 1996:48). 
White en Epston (1990:18-32) wys daarop hoe ook Foucault sterk gefokus het op prosesse wat sosiale konstruksies in 'n samelewing legitimeer en reification in die hand werk. 'n Belangrike funksie in hierdie legitimering is dié van sogenaamde expert opinion, waardeur mense onderwerp word aan power-knowledge. Subtiele meganismes en magstegnieke werk mee in die legitimeringsprosesse. "Ingeligtes" en "kundiges" - die draers van expert opinion - se gesag word versterk deur bepaalde posisies wat hulle beklee en bepaalde rolle wat hulle speel binne bepaalde instellings. Hulle tree met outoriteit op, en die waarhede wat hulle oordra kan beskou word as outoritêre waarheid. Hier is nie meer sprake van tentatiewe, soekende, gesamentlike konstruerings nie.

Taal en narratief speel 'n besonder belangrike rol in prosesse van legitimering van gekonstrueerde kennis. Stories is kragtige middele wat die stereotipes van 'n kultuur illustreer en oordra (Langellier \& Peterson 1993:50). Vertellers van stories is in outoritêre posisies vanwaar hulle eie voorkeurweergawes van gebeure kan deurgee aan luisteraars of lesers (Zelizer 1993:189-190). Sekere stories kry groter gesag as ander. 'n Dominante storie kan beskryf word as "dominant knowledge and unit of power" (White \& Epston 1990:15, in aansluiting by Goffman 1961). Godsdiens speel ook 'n belangrike rol as legitimeringsfaktor in die proses van reification. Die gesag van die patriargie byvoorbeeld word gelegitimeer deur die vaderskap van God, die Een met die laaste sê, die Almagtige.

Die modernistiese werklikheidsbeskouing is 'n belangrike legitimeringsfaktor in die proses van reification (Freedman \& Combs 1998:20). Legitimiteit word aan uitsprake verleen op grond van vermeende objektiwiteit in subjek-objekverhoudings (Elam 1992:140; Marshall 1992:101, 105, 117, 181, 182). Legitimering van reification geskied ook deur 'n beroep op tradisie, die feit dat bepaalde sosiale konstruksies al dikwels herhaal is met verloop van tyd. Tradisievorming het in die feudalisme plaasgevind onder leiding van outoriteit wat gesetel het in hiërargie, struktuur en religie. Modernisme ontsnap egter ook nie aan die proses van tradisie-vorming nie, en vorm algaande 'n "modernist tradition" (Richardson 1995:53). Tradisie verword tot tradisionalisme in die proses van reification. 
In die pastoraalterapeutiese prosesse wat beskryf word in my navorsing blyk hoe moeilik dit is vir mense om weerstand te bied en aan kennis-mag te ontsnap wanneer bepaalde gestaltes daarvan vir hulle tot probleem geword het.

\subsubsection{Dekonstruksie van sosiale konstruksies}

Dekonstruksie staan in spanning met tiperings, instellings en tradisies, maar opponeer dit nie (Derrida 1997:5-6). Dit opponeer wel reification en belig die gekonstrueerdheid teenoor vermeende gegewenheid - van alle filosofie, wetenskap, ideologie, politiek, teologie en instellings (Ijsseling 1986:13).

\subsection{Kontoere/raamwerke vir Christelike teologie in 'n postmoderne tyd}

"The challenge for the church is to claim the postmodern context for Christ" (Dockery 1995:15). Ek sluit aan by teoloë wat die uitdaging aanvaar om teologie te beoefen met sensitiwiteit vir die postmoderne gesteldheid.

\subsubsection{Teologie as diskoers, gesprek oor God}

Teologie kan beskou word as diskoers oor God (Derrida 1998:15). Die teologiese gesprek is 'n oop gesprek waaraan nie net persone met Christelike geloofsoortuigings deelneem nie (Du Toit 1995:6). Ook "gewone" gelowiges, in onderskeiding van "beroepsteoloë", neem aan die gesprek deel (Roux 1996:51). "Beroepsteoloë" gaan wel meer sistematies-gestruktureerd te werk (Müller 1996:5) en verreken meer moontlikhede.

\subsubsection{Teologie wat bou op 'n geloofskeuse}

Die saak van die Christelike teologie is die saak van die evangelie van Jesus Christus (Pieterse 1993:2). In diskoers word kennis vermeerder oor die moontlikhede in Jesus Christus. Die aanvaarding/keuse van bepaalde moontlikhede as waar, is egter 'n geloofskeuse, en daarmee saam 'n onstabiele keuse - in die afwys van ander moontlikhede. Jesus kan aanvaar word as die wysheid van God of afgewys word as dwaasheid oor God (1 Kor 3:18-19). God bly verborge, ook in sy openbaring (Stroup 1981:40-44). Postmoderne teologie gee ruim plek vir die konsep van misterie (Grenz 
1995:98-101). Die rasionele is radikaal onvoldoende om as leidende beginsel van ons geloof ons lewens te rig.

\subsubsection{Spirituele teologie}

Spiritualiteit dui op in-verhouding-wees. Dit is vir die postmoderne gesteldheid belangriker as die formele inhoud en vormgewing aan kennis wat binne hierdie verhoudings gekonstrueer word (Grentz 1995:100, 101). Postmoderne Christelike teologie maak 'n post-fundamentalistiese skuif weg van 'n belydenisgebasseerde identiteit, en wel na 'n spiritualiteitgebaseerde identiteit (Du Toit 2000:144). 'n Rasionalistiese teologie neig om "waarheid" te probeer vasvang in stellings en dogmas.

\subsubsection{Post-individuele teologie}

Ek bedryf teologie in verbondenheid aan die messianism (Derrida 1997:22-23) wat die Christelike taal praat, wat Jesus Christus as Here bely. "God is known in the church of Jesus Christ" (Barth 1957:3). Ons moet erkenning gee aan die belangrikheid van die geloofsgemeenskap en ons deelwees daarvan, vir ons verhouding met God en kennis van God (Grenz 1995:100).

\subsubsection{Nie-tradisionalistiese teologie}

Ekself is gevorm binne die Gereformeerde tradisie. Geen tradisie behoort egter as van sentrale belang beskou te word nie en behoort ook nie fundamentalisties in stand gehou te word nie. Postmoderne teologie stuur weg van tradisionalisme soos dié van Mohler (1995:81, 83) wat wil terugkeer na die vermeende universele waarheid van die kerk se meta-narratief, en "to the careful study and respectful following of the central traditions of classical Christian exegesis" (Oden, in Mohler 1995:83).

\subsubsection{Erkenning van taal as immanent verwysend}

Religieë is sosiale konstruksies (Lindbeck 1996:227) met taal - insluitende Bybelse taal wat relatief is tot die kontekste en perspektiewe van bepaalde kulture. Bybelse taal is nie 'n weerspieëling van die goddelike of die geskape werklikheid nie. Hierdie perspektief is 'n wegbeweeg van Glodo (1995:152) se fundamentalisme waarvolgens God 'n menigte 
metafore en beelde sou ingestel/vasgestel het waardeur ons transendente werklikheid sou kon sien.

Taal is immanent verwysend (Du Toit 1995:iv-x, 82). Teologie, soos ook die Bybel self, is menslike spreke oor God, deel van die immanent-verwysende taalspel van betekening, play of difference, différance, te midde van nimmereindigende konteksverruimings en konteksverskuiwings. Ons is vasgevang in die eindelose net van tekstualiteit, "actors lose themselves in the infinity of the play" (Taylor 1982:74).

\subsubsection{Teologie wat openbaring as misterieuse moontlikheid verreken}

Postmoderne teologie verreken wel die transendente/Goddelike en openbaring as moontlikhede, soos wat Derrida (1998) dit ook doen, sonder om soos Altizer (1982:158) in modernistiese onderskeidings terug te val. Die moontlikheid van openbaring binne die différance-taalspel van die mens is 'n wonder-moontlikheid, nie te bewys of te verwerp vanuit die taal van die Bybel self nie.

\subsubsection{Teologie wat die radikale andersheid van die ander eties verreken}

Etiese verantwoording tot die ander staan sentraal in die postmodernisme (Turner 1994:4). Geregtigheid hang ten nouste saam met die erkenning van heterogeniteit (Turner 1994:9, 11). Die ander is radikaal anders, nie reduseerbaar tot identies of dieselfde nie. "Theology should ... refuse the domestication of the other as well as the isolation from the other" (Du Toit 1995:363). Die radikaal ander moet deur die radikale van die liefde (Mt 22:37-39) benader word.

\subsubsection{Dekonstruktiewe teologie}

Dekonstruktiewe teologie vind aansluiting by 'n hermeneutiek van suspisie (Tracy 1991:53). Elke interpretasie laat die suspisie van meer, van anders, van moontlikhede wat buite rekening gelaat is. Dekonstruktiewe teologie kan daartoe meehelp dat geen finale, dominerende prentjie of meta-narratief voorgehou word deur modernistiese teologiese waarheidsaansprake nie (Du Toit 1995:364). Deur te wys op die relatiwiteit vanweë verskeie interpretasiemoontlikhede, vra dekonstruktiewe teologie dat gehoorsaamheidseise (van God?) nie brutaal benader word op grond van 'n vermeende duidelike en onmiddellike openbaring van God nie (Du Toit 1995:350). 


\subsubsection{Narratiewe teologie}

"A strain of relativism runs through most narrative theology" (Bloesch 1994:210). Dit bring ' $n$ openheid mee om ander se perspektiewe te waardeer en daarna te luister, en stuur weg van kritiek en konfrontasie. Postmoderne narratiewe teologie beoog egter nie die beskrywing van "die werklikheid" of die wese van God nie. Dit fokus op praktiese waarheid (Bloesch 1994:209), waarheid as singewing. Verhale word ontwikkel ter wille van identiteitsbeskrywings.

\subsubsection{Narratiewe pastoraat}

Een van die kernverhale van die Christen-geloofsgemeenskap is die verhaal van die heilsbetrokkenheid van God by mense en die wêreld (Stroup 1981:95; Veltkamp 1988:119, 125, 130). Die pastor moet self leef van die verhaal(e) van God se betrokkenheid by die mense, en moet die ander uitnooi om daarvan te leef. Hierdie verhaal oor/van God word ingeskryf binne die verhale van diegene in die pastorale proses, en hulle skryf hulle verhale in die konteks, in die lig, van "God se Verhaal"3 (Kotzé \& Botha 1994:392).

Die pastor soek na raakpunte tussen die verhale van mense en die geloofsgemeenskap se verhale oor God se geskiedenis met die mense. Hierdie verhale van die geloofsgemeenskap kom nie noodwendig in elke gesprek ter sprake nie. Soos Veltkamp, beskou Stroup ook die verhale van die ander - insluitende hul interpretasies van die betrokkenheid van God in hul lewens - as van primêre belang in pastorale gesprekvoering. In die pastoraat word met mense in gesprek gegaan en betrokke geraak by hulle verhale van nood (Müller 1996:107). In die lig daarvan kom die pastor en geloofsgemeenskap se interpretasies ter sprake. Die verhale van die Christen-geloofsgemeenskap oor God se betrokkenheid kan in botsing kom met mense se eie verhaalde identiteit. Daar kan egter ook, deur die geheimenisvolle gebeure van openbaring, 'n herinterpretasie van persoonlike identiteit plaasvind, die realisering van 'n nuwe Christelike identiteit. Nuwe verhale wat getuig van Christelike identiteit as 'n lewe in Christus en deur die Gees, word sodoende gekonstrueer.

\footnotetext{
${ }^{3}$ Ek verkies om te praat van 'n verhaal oor God, of van 'n verhaal van God se betrokkenheid. Dit moet altyd duidelik wees dat verhale sosiale konstruksies is. Dit is in lyn met my keuse om eerder van die Bybel te praat as woorde oor God, in plaas van Woord van God. Daarmee ontken ek nie die moontlikheid dat woorde oor God ook woorde van God kan wees of word nie. Ek sluit aan by Du Toit (1995:265) wat die Bybel as besondere openbaringsoord beskou. Ek sluit egter ook aan by Stroup (1981:44) wat konstrueer dat openbaring altyd verwys na die spesifieke gebeure waarin God se Woord gespreek word. Die Bybel is menslike woorde waarin 'n mens deur die geloof God se Woord kan hoor.
} 
Lojaliteit teenoor en verteenwoordiging van die Christelike storie oor God se betrokkenheid staan dikwels in spanning met die empatiese betrokkenheid by die lewensverhale van mense. Pastorale werk binne die spanning van dialoog en oop gesprek behels altyd die beweging van kant tot kant (Gerkin 1997:112). Deur dekonstruktiewe betrokkenheid word ander moontlikhede na vore gebring as wat die probleemversadigde noodverhaal aanvanklik bied. Mense word begelei op die weg na nuwe verhale, nuwe interpretasies, en daardeur ook na nuwe identiteit.

Sosiaal konstruktief en dekonstruktief, in différance, word saam beweeg na verhale wat meer sin mak en meer hoopvol is met die oog op die toekoms. Narratiewe en dekonstruktiewe pastorale betrokkenheid is 'n totaal ander benadering as om met ' $n$ paar strukturele en behavioristies-manipulerende skuiwe verandering te bewerk of mense in te praat in bekeringsbesluite (Müller 1996:29).

\section{SLOTWOORD}

Daar is nie in hierdie artikel gereflekteer op die konkrete handelinge wat binne die prosesse plaasgevind het nie. Dit was vir my belangrik om eers my posisionering as navorsing duidelik te maak. In voortgaande gesprekke sou gereflekteer kon word oor die inhoudelike van die prosesse wat plaasgevind het, sowel as op reflekterings daarop.

Hierdie navorsing het my gehelp in my strewe om as postmoderne, Christelikpastorale, narratiewe terapeut betrokke te wees in die lewens van mense. Grense, binêre teenstellings, tradisionele rolle, hiërargieë en sogenaamde objektiewe kundigheid het vir my algaande minder belangrik geword en ek kon meer fokus op verhoudinge waarbinne mense mekaar as gelykes ontmoet en saam probeer sin mak van dilemmas binne bepaalde kontekste. Ek het geduldiger geword met kompleksiteit en die chaotiese, en meer akkommoderend/verdraagsaam teenoor andersheid. Ek het my al meer verwonder oor die andersheid van God, en die geheimenis van sy openbaring. Dit het my gehelp om met minder sekerheid, maar tog ook coram Deo, in groot geloofsvreugde, met God te lewe en te leer hoe andere met God saamlewe in Christus Jesus. 


\section{Literatuurverwysings}

Altizer, J J 1982. History as apocalypse, in Altizer, J J, Myers, M A, Raschke, C A, Scharlemann, R P, Taylor, M C \& Winquist, C E (eds), Deconstruction and theology, 147-177. New York: Crossroad.

Anderson, H \& Goolishian, H A 1988. Human systems as linguistic systems: Preliminary and evolving ideas about the implications for clinical theory. Family Process 27, 371-393.

Bakan, D 1996. Some reflections about narrative research and hurt and harm, in Josselson, R (ed), Ethics and process in the narrative study of lives, 3-9. Thousand Oaks, London: Sage.

Barth, K 1957. Church dogmatics, Vol 2/1: The doctrine of God, ed by G W Bromiley \& T F Torrance, tr by T H L Parker, W B Johnston, H Knight \& J L M Haire. Edinburgh: T \& T Clark.

Bloesch, D G 1994. Holy scripture: Revelation, inspiration and interpretation. Downers Grove, Il: Intervarsity Press.

Browning, D S 1991. A fundamental practical theology: Descriptive and strategic proposals. Minneapolis, MN: Fortress.

Brueggemann, W 1993. Texts under negotiation: The Bible and postmodern imagination. Minneapolis, MN: Fortress.

Bybelgenootskap van Suid-Afrika 1983. Die Bybel: Nuwe vertaling. Goodwood, Kaap: Nasionale Boekdrukkery.

Caputo, J 1989. Mysticism and transgression: Derrida and meister Eckhart, in Silverman, H J (ed), Derrida and deconstruction, 24-39. New York: Routledge. (Continental Philosophy 2.)

Caputo, J 1997. A commentary: Deconstruction in a nutshell, in Caputo (ed), Deconstruction in a nutshell: A conversation with Jacques Derrida, 31-208. New York: Fordham University Press.

Chase, S E 1996. Personal vulnerability and interpretive authority in narrative research, in Josselson, R (ed), Ethics and process in the narrative study of lives, 45-59. Thousand Oaks, London: Sage. 
De Jager, J J 2001. Die dekonstruksie van tradisionele probleem-realiteite in 'n plattelandse gemeenskap: 'n Narratief-pastorale perspektief. PhD tesis, Universiteit van Pretoria.

Derrida, J 1976. Of grammatology, tr with additional notes, by G C Spivak. Baltimore: The Johns Hopkins University Press.

Derrida, J 1982. Margins of philosophy, tr with additional notes, by A Bass. Chicago, Il: The University of Chicago Press.

Derrida, J 1988. Letter to a Japanese friend, in Wood, D \& Bernasconi, R (eds), Derrida and différance, 1-6. Evanston, Il: Northwestern University Press.

Derrida, J 1996. Remarks on deconstruction and pragmatism, in Mouffe, C (ed), Deconstruction and pragmatism: Simon Critchley, Jaques Derrida, Ernesto Laclau, Richard Rorty, 77-88. London: Routledge.

Derrida, J 1997. The Villanova roundtable: A conversation with Jacques Derrida, in Caputo, J D (ed), Deconstruction in a nutshell: A conversation with Jacques Derrida, 3-28. New York: Fordham University Press.

Derrida, J 1998. Faith and knowledge: The two sources of "religion" at the limits of reason alone, tr by Weber, S, in Derrida, J \& Vattimo, G (eds), Religion, 1-78. Cambridge: Polity.

De Villiers, M, Smuts, J, Eksteen, L C \& Gouws, R H 1985. Nasionale woordeboek. $6^{\mathrm{e}}$ uitgawe. Goodwood, Kaap: Nasionale Opvoedkundige Uitgewery.

Dockery, D S 1995. The challenge of postmodernism, in Dockery (ed), The challenge of postmodernism: An evangelical engagement, 13-18. Wheaton, Il: Victor Books.

Du Toit, B 2000. God? Geloof in 'n postmoderne tyd. Bloemfontein: CLF.

Du Toit, S F 1995. Ideas of truth and revelation in the light of the challenge of postmodernism. PhD thesis, University of Oxford.

Elam, D 1992. Romancing the postmodern. London: Routledge.

Epston, D, White, M \& Murray, K 1992. A proposal for a re-authoring therapy: Rose's revisioning of her life and a commentary, in McNamee \& Gergen (eds), Therapy as social construction, 96-115. London: Sage. 
Farrell, F B 1994. Subjectivity, realism, and postmodernism: The recovery of the world. New York: Cambridge University Press.

Freedman, J \& Combs, G 1996. Narrative therapy: The social construction of preferred realities. New York: Norton.

Gasché, R 1987. Infrastructures and systematicity, in Sallis, J (ed), Deconstruction and philosophy: The texts of Jacques Derrida, 3-20. Chicago, Il: The University of Chicago Press.

Gergen, K J 1994. Realities and relationships: Soundings in social constructions. London: Harvard University Press.

Gerkin, C V 1997. An introduction to pastoral care. Nashville, TN: Abingdon.

Glodo, M J 1995. The Bible in stereo: New opportunities for biblical interpretation, in an a-rational age, in Dockery 1995:148-172.

Grenz, S J 1995. Star Trek and the next generation: Postmodernism and the future of evangelical theology, in Dockery 1995:89-103.

Ijsseling, S (red) 1986. Jaques Derrida: Een inleiding in zijn denken. Rotterdam: Ambro Rotterdam.

Ijsseling, S 1986. Jacques Derrida: Schrijven, in de marge, in Ijsseling, S (red), Jaques Derrida: Een inleiding in zijn denken, 9-27. Rotterdam: Ambro Rotterdam.

Josselson, R (ed) 1996. Ethics and process in the narrative study of lives. London: Sage.

Kotzé, D J \& Botha, A 1994. Die pastorale fasilitering van huweliksgroei by egpare met behulp van familie-van-oorsprong-werk. NGTT 35, 389-399.

Lamprecht, N E 1996. Geslagsrolidentiteit: 'n Prakties teologiese ondersoek na die patriargale geslagsrolstereotipe en geloofsvolwassenheid. DD-proefskrif, Universiteit van Pretoria.

Langellier, K M \& Peterson, E E 1993. Family storytelling as a strategy of social control, in Mumby 1993:49-76.

Lax, W D 1992. Postmodern thinking in clinical practice, in McNamee \& Gergen 1992:69-85.

Lieblich, A, Tuval-Mashiach, R \& Zilber, T 1998. Narrative research: Reading, analysis, and interpretation. London: Sage. 
Lindbeck, G A 1996. Atonement and the hermeneutics of intratextual social embodiment, in Phillips, T R \& Okholm, D L (eds), The nature of confession: Evangelicals and postliberals in conversation, 221-240. Downers Grove, Il: InterVarsity Press.

Marshall, B K 1992. Teaching the postmodern: Fiction and theory. New York: Routledge.

McNamee, S \& Gergen, J (eds) 1992. Therapy as social construction. London: Sage.

Mishler, E G 1986. Research interviewing: Context and narrative. Cambridge, MS: Harvard University Press.

Mohler jr, R A 1995. The integrity of the evangelical tradition and the challenge of the postmodern paradigm, in Dockery 1995:67-88.

Moyaert, P 1986. Jacques Derrida en de filosofie van de differentie, in Ijsseling 1986:2889.

Müller, J 1996. Om tot verhaal te kom: Pastorale gesinsterapie. Pretoria: RGN.

Müller, J 2000. Reis-geselskap: Die kuns van verhalende pastorale gesprekvoering. Epping, Wes-Kaap: Creda Communications.

Müller, J, Van Deventer, W \& Human L 2001. Fiction writing as metaphor for research: A narrative approach. Praktiese Teologie in S A 16, 76-96.

Mumby D K (ed) 1993. Narrative and social control: Critical perspectives. Newbury Park, London: Sage. (Sage Annual Reviews of Communication Research 21.)

Nealon, J T 1993. Double reading: Postmodernism after deconstruction. Ithaca, NY: Cornell University Press.

Owen, A S 1993. Oppositional voices in China Beach: Narrative configurations of gender and war, in Mumby 1993:207-231.

Pieterse, H J C 1993. Praktiese teologie as kommunikatiewe handelingsteorie. Pretoria: RGN.

Polkinghorne, J 1996. Beyond science: The wider human context. Cambridge: The University Press.

Richardson, K A 1995. Disorientations in Christian belief: The problem of detraditionalization in the postmodern context, in Dockery 1995:53-66. 
Roux, J P 1996. Die ontwikkeling van 'n pastoraal-terapeutiese toerustingsprogram vir lidmate: 'n Narratiewe benadering. PhD-proefskrif, Universiteit van die OranjeVrystaat.

Scheurich, J J 1997. Research method in the postmodern. London: The Falmer Press. (Qualitative Studies 3.)

Stroup, G W 1981. The promise of narrative theology: Recovering the gospel in the church. Atlanta, GA: John Knox.

Taylor, M C 1982. Text as victim, in Altizer et al 1982:58-78.

Tracy, D 1991. Hermeneutical reflections in the new paradigm, in Küng, H \& Tracy, D (eds), Paradigm change in theology: A symposium for the future, tr by M Köhl, 3462. New York: Crossroad.

Turner, B S 1994. Orientalism, postmodernism and globalism. London: Routledge.

Veltkamp, H J 1988. Pastoraat als gelijkenis: De gelijkenis als model voor pastoraal handelen. Kampen: J H Kok.

White, M \& Epston, D 1990. Narrative means to therapeutic ends. New York: W W Norton.

Zelizer, B 1993. American journalists and the death of Lee Harvey Oswald: Narratives of self-legitimation, in Mumby 1993:189-206. 